\title{
THE ROLE OF RITUAL TRADITIONAL CLOTHING AMONG BUNJEVCI CROATS IN SERBIA IN THE REVITALISATION OF ANNUAL CUSTOMS AND RITUALS
}

\author{
Milana Černelić
}

\begin{abstract}
The article deals with the traditional costume worn in the course of calendar festivals and the feast marking the end of the harvest among a Croatian subethnic group in the region of Bačka (county of Vojvodina) in Serbia. The traditional costume carries an important symbolic meaning in the process of revitalising customs and, as such, it represents an ethnocultural identity marker of the group. The customs analysed have undergone a great revival in the past twenty years, being observed in certain calendar periods or on specific days during the ritual year, such as the central cultural and social event - the prelo (spinning bee) in the winter period of Shrovetide, and the Pentecost pageant called kraljice, as well as on the occasion of the Dužijanca, a celebration marking the end of the harvest among the Bunjevci Croats in the region of Bačka, which has existed as a public event for over a century. The article is based on the actual field data gathered by the author and her associates.
\end{abstract}

Keywords: annual customs, Bunjevci, Dužijanca (harvest celebration), kraljice (Pentecost pageant), prelo (spinning bee), St. John's Day, traditional costume

\section{INTRODUCTION: THEORETICAL ANNOTATIONS}

In an attempt to understand the reality which we live (in), we often rely on ethnology and cultural anthropology. As a conceptual science it directs us, theoretically and methodologically (with the pertaining terminology), towards the definitions and concepts of culture and identity, i.e. towards the cultural and identification strategies and practices that can be used for categorising and classifying communities in the introspection process and the process of interaction with others: throughout centuries of changes, what has led and maintained a community is confidence and self-respect, the feeling of affiliation and continuity. This implies that each community has a name, space, history, tradition, and culture, a consensus as to its common origin, the feeling of sameness and the feeling of togetherness and belonging. In other words, identification processes and practices emphasise the objective dimension (cultural 
repertoire) and the subjective dimension (emotions and loyalty). Both dimensions are constantly being transformed and never appear in any sort of 'original form'. At the same time, however, they imply the existence of certain constants, i.e. belief, thought, and statement on the duration and continuum on which rests the basis of togetherness. In the last fifty years, referring to the notion 'search for identity', anthropological literature has produced numerous and often contradictory theories directed towards the affirmation and reaffirmation of cultural, ethnic, national, and other identities, such as regional ethnocultural identities of minority communities. Some of them foresee the de-ethnicisation and overall homogenisation of society. However, the strengthening of ethnicism and regional identities in the last two decades points to a different direction of thought. This is supported by pragmatism and historical experience (Černelić \& Grbić Jakopović 2013: 500-501).

Identity lives in objective cultural contents, in which tradition has a special status, since tradition is (still) a pool from which ethnical and cultural markers - media for ascription and identification - are in most cases selected. This tradition is not original, but it is modified and transposed in each coming new era, since we can recognise the variability of identities in this new modification of, so to speak, 'originality': being the same but always in a different way (Banac 1992: 88). Identity co-exists on the global and local levels: in, at, and beyond borders. People become aware of their culture when they become aware of its borders, i.e. when something different and diverse appears, or something that departs from what is usual or normal: the norm becomes the border, a symbolic sense of recognition and consolidation of identity. What is also important for the process of symbolic identification is the notion of what we have 'inside' and what is different from that (Cohen 1985). Identity also exists in historicity. By selective (re)constructing of the past and by discovering references from the past and referring to them, each generation finds its reflection in the contemporaneity (Budak 1999, Heršak 1999; cited in Černelić \& Grbić Jakopović 2013: 501). To conclude, genesis, limits, symbols, common destiny, and traditional customs are evidence that the stability of the identification process, as well as its final result - identity - in spite of everything, can remain undisputed for a long time.

\section{A SHORT OVERVIEW ON BUNJEVCI}

Serving as proper evidence of the mentioned processes, there are some ritual annual customs that are an expression of the symbolic identification of the Croatian subethnic group (at the same time a national minority) in the multiethnic environment of the region of Bačka (county of Vojvodina) in Serbia. I will be 
focusing on the importance of their traditional costume worn in the course of calendar festivals and the feast marking the end of the harvest. The ethnonym Bunjevci stands for the group of ethnic Croats, originating from Dalmatia, south-western Bosnia and Herzegovina. In the 17th century, they migrated to the regions of Primorje (the Croatian Littoral), Lika, and Gorski kotar, situated in western Croatia, and to the Danube area in the north (the former AustroHungarian Empire, today the territories of Hungary and Serbia), thus forming the three basic remote branches of the ethnic group of Bunjevci, known as Dalmatia, Primorje/Lika, and the Danube-area Bunjevci (Černelić 2006: 13). A short account of their contemporary position as a national minority in Serbia is necessary for better understanding of the position of the Bunjevci subethnic group in Bačka. During the 20th century, the Bunjevci were under constant questioning and politicising of their ethnicity. These were in fact the attempts to deny the rights of the Bunjevci of Bačka to belong to Croatian nation during the existence of the Kingdom of Serbs, Croats, and Slovenes between the two world wars (from 1929 the state was renamed as the Kingdom of Yugoslavia).

Under the cover of the common name 'Yugoslav' for the three peoples living in one state, three basic forms of manipulation with the ethnonym Bunjevci came to light: 1. neutralization of the Bunjevci by emphasizing their distinctiveness: they are neither Serbs nor Croats; one explanation being that they are the fourth tribe of the unique Yugoslav people, and the other one that they are the fourth nation of the Kingdom of Serbs, Croats and Slovenes. 2. The Bunjevci can be both Serbs and Croats, which is a matter of an individual choice; it is irrelevant anyway, since both Serbs and Croats are in fact Yugoslavs. 3. Denial of the Croatian ethnicity of Bunjevci, by manipulating their religious belonging, expressed in the claim that the Bunjevci, as well as the Šokci, are Serbs of Roman Catholic religion. (Černelić 1997: 178)

Writings of the kind can be found in different forms in various published sources.

In the period of the Socialist Federal Republic of Yugoslavia, the question of Croatian national affiliation of the Bunjevci subethnic group was not posed directly, but, by the means of the proclaimed 'Yugoslavianism', all the institutions in Vojvodina lost their Croatian mark already in 1956, by a politicaladministrative ban (Žigmanov 2006: 20). The number of Croats in Vojvodina decreased in the 1990s, during the period of the war between the Republic of Croatia and Serbia and Montenegro, as a result of their deportation, property devastation, creation of the atmosphere of fear and insecurity, threats expressed through media propaganda, etc. All of the mentioned factors led to mass emigration and a flight into ethnic mimicry. In the given context the policy of 'the 
Bunjevci nation' was successfully established (ibid.: 26). ${ }^{1}$ At that time, for the first time in their history, all Croatian ethnic groups in Vojvodina were detached from their parent country fellow-citizens by a national border for a longer period of time. Thus a subethnic group was turned into a national minority (ibid.: 21). Besides, Croats in Vojvodina waited to receive the status of a national minority for more than ten years after the disintegration of Yugoslavia. In the law on the protection of rights and freedoms of national minorities from 2002 the provided legal definition of a national minority is not a classic definition thereof but of an ethnic group, thus levelling out the two substantially different terms and consequently creating a formal legal space for misuse, which has indeed occurred in the case of the subethnic group of Bunjevci (ibid.: 27-30). This was further facilitated by the census possibility in 1991 and 2002 to declare oneself as a member of the Bunjevci or Šokci for the first time, ${ }^{2}$ which renewed the tendency of manipulating ethnicity, and supported the idea of Slobodan Milošević's regime to encourage the process of a parallel 'construction of a nation' based on the subethnic and regional names of Croats (ibid.: 22).

In their attempt to place the problem of the Bunjevci identity in the context of contemporary theories, some authors put the Bunjevci in the category of stateless ethnic groups (Prelic 2008: 190). In this way the issue of objective determination of national affiliation of the Bunjevci is further obscured, and the fact that the Bunjevci in Bačka are not an independent ethnic group but were resettled and dispersed in several branches in the past is being neglected. The tendencies that had originated in the first half of the 20th century reappeared in the early nineties. Some members and associations of the Bunjevci subethnic group use the ethnonym again as a mark of their national belonging, denying belonging to the Croatian nation, and stand in opposition to other Bunjevci representatives who declare themselves as Croats. Such polarisation has been stimulated with the isolation of the ethnonym Bunjevci as a special ethnic category, starting with the census of 1991 in the former Yugoslavia, up to the present day in Serbia. Both of the opposed Bunjevci groups share common ethnocultural heritage, but the subjective perception of their ethnic identity is different (Černelić 2012: 172-173). I deal with the Bunjevci who declare themselves as Croats in the interviews conducted during my fieldwork. The research is based on the interviews combined with the actual observing of these customs between 2011 and 2014, as part of a scientific project dealing with the heritage and identity of the Croatian subethnic group of the Bunjevci. ${ }^{3}$ 


\section{THE TRADITIONAL COSTUME AS AN IDENTITY MARKER DURING THE CALENDAR YEAR}

Vojvodina is a multiethnic and multicultural province, and each subethnic group and/or national minority has a specific traditional costume, which for each of them has an important symbolic meaning. As such it represents an ethnocultural identity marker of each particular group. I deal with the traditional costume worn by the Bunjevci Croats in the process of revitalisation of their annual customs and on the occasion of the feast marking the end of the harvest. Some of these customs have undergone a great revival in the past twenty years, being observed in certain calendar periods or on specific days during the ritual year, such as the central cultural and social event - the prelo (spinning bee) - in the winter period of Shrovetide, and the kraljice (Pentecost pageant). In addition to the festive calendar year, the traditional costume has an important continual role on the occasion of the Dužijanca, a celebration marking the end of the harvest among the Bunjevci Croats in the region of Bačka, which has existed as a public event for over a century. I am going to provide an overview on the use of the traditional clothing on these various occasions with a special focus on its significance as an identity marker and a symbolic object.

For this purpose it is necessary to provide some basic information about the traditional folk costume that is most often used in the revitalised customs. ${ }^{4}$ The basic parts of the traditional female costume are always the same, regardless of the type of the costume: a shirt, 7-9 petticoats, a skirt (both cut out of 5-6 parts), a waistcoat, and an apron. In the 19th century and in earlier times the materials were woven from home-made hemp and flax, later alternated with cotton, but as early as the end of the 19th century they were replaced with manufactured materials both for everyday and ceremonial costumes. A characteristic part of the Bunjevci female costume was the igrač - a belt made of the appropriate material, depending on the occasion, 15-20 centimetres wide and 3 metres long, tied into a bow around the waist. Women wore a kerchief over the hair, called konda or kapica, and a scarf over their shoulders. Since the late 19th century the ceremonial silk costume made of manufactured silk, which relatively wealthy peasants purchased from the famous silk factory in Lyon in France, has formed a recognisable marker of the Bunjevci identity. Since that time the girls' characteristic costume has been a white cotton costume, each part of which is decorated with white embroidery (šlinga). The everyday costume was also made of different manufactured cotton materials with various ornaments: the sefir for girls, with characteristic vertical stripes, the paja for older women, consisting of a wool skirt and a cotton shirt (parketski leveš), most often having a tartan ornament, and so on. The function of the everyday 
costume has also transitioned into a ceremonial one nowadays. In wintertime the most characteristic pieces of female clothes are different types of coats: the ceremonial čurdija made from a scarf and welted with fox fur, decorated with silver buttons and ribbons made of various materials (leather, wool, silk, silver or golden threads), with a specific narrow waist. Other winter coats are made of similar materials, differently cut and less decorated. The basic parts of the traditional male costume are: a shirt, wide pants (each pant leg being cut out in two parts), and a waistcoat. The ceremonial costume differed from the everyday one in material and decoration. In winter men wore trousers over pants, different types of decorated ceremonial dolman jackets (dolama or reklija), sheep fleece waistcoats (pršnjak), and long fleece robes (opaklija).

Under the influence of urban fashion, both male and female costumes changed in different periods. ${ }^{5}$

\section{PRELO}

The complex phenomenon of the prelo (spinning bee), which consists of various social gatherings during the period of Shrovetide, is one of the important customs belonging to the Bunjevci traditional heritage. Veliko prelo (the Great Spinning Bee), the most important event of the period in the form of a public festivity, is held in Subotica, the administrative and cultural centre of the Bunjevci Croats. After a long break it has undergone a great revival in the past twenty years, today being the central cultural event in the winter period, socially particularly important to the Bunjevci in northern Bačka. Along with Veliko prelo, many similar smaller gatherings are organised during that period in Subotica and Sombor (another urban settlement in Bačka), and in the surrounding Bunjevci rural settlements. In earlier times such gatherings were traditionally held in rural settlements, on the Bunjevci farms, which represented the central institutions of rural life in the Bačka region. As a family gathering combining spinning and other textile crafts and entertainment, the prelo survived up to the 1970s. In its latest stage it was coupled with pig slaughter, another tradition characteristic of the winter period, although those were originally two different traditions (Dronjić 2014: 118-120). Veliko prelo was first held as a public festivity, concurrently with the family prelos, in Pešta hotel in Subotica, in 1879, in the period of the national revival of the Croats in Bačka. The festivity continued to exist until the mid-20th century, with a short break during the First World War. It was revived in the 1990s. Since then it has been held every year in the great hall of the Croatian Cultural Centre Bunjevačko kolo (meaning: Bunjevac wheel dance). In 2015 several other cultural associations organised it together 


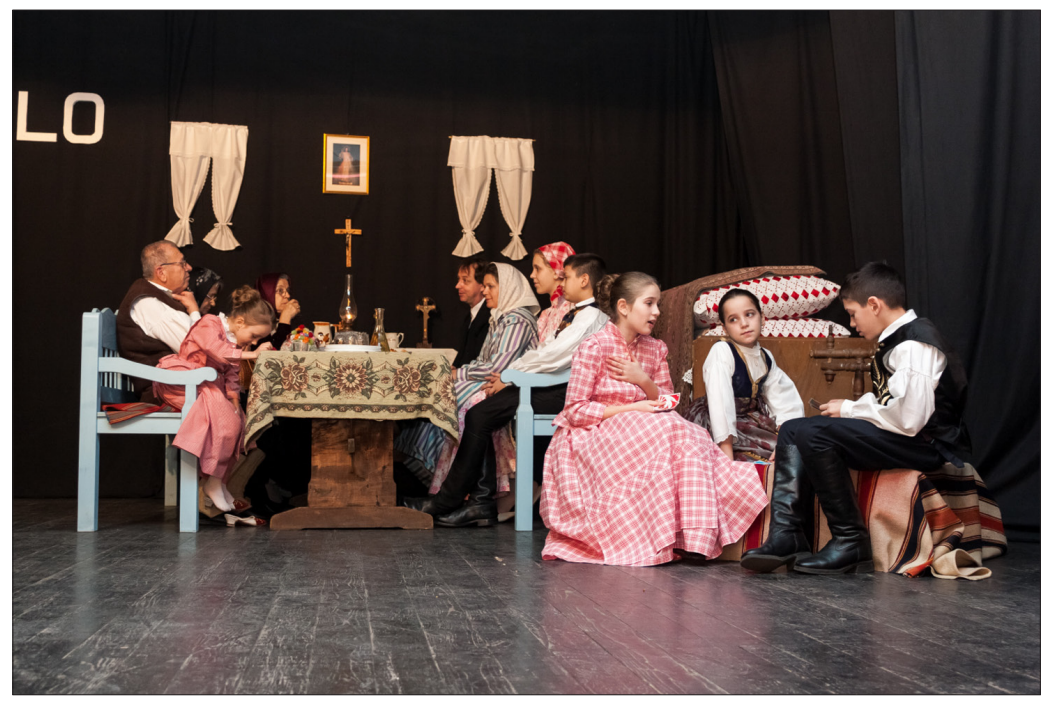

Figure 1. Reconstruction of the prelo on stage. Photograph by Matija Dronjić 2012.

for the first time; earlier on they had each organised their own prelo during the period of Shrovetide.

The traditional dress used to be obligatory in the 19th century when the public festivity was initiated. Nowadays it is not obligatory anymore, but some participants appear in traditional costumes, most often the organisers and their families. The guests are welcomed by girls dressed in folk costumes, and each of them gets a handkerchief with the embroidered motif of the spinning bee, the same motif being on the invitation card. The programme leaders are dressed in folk costumes, along with all the participants who perform the original family spinning bee on stage as well as those who play and sing on the stage (Fig. 1).

An important part of the programme, besides singing and dancing, is also a fashion show of the traditional costumes, wherein the best dressed and bestlooking girl is proclaimed (Fig. 2) (ibid.: 120-132).

In 2011 another event came into existence - the prelo sićanja (the Memory Spinning Bee) (Fig. 3). Its aim is to revive and represent the original prelo, which means that the traditional costume is a necessary prerequisite for participation. The reason behind its initiation is nostalgia. One of the organisers, Ivan Piuković, has explained that it serves to remind the older members of the community of the good old days, of what the prelo looked like in the past, as well as to teach the young about it and to continue the tradition (cf. Sudarevic 2012). The participants gather in front of the Town Hall; then they attend the Holy Mass in the nearby Franciscan church. ${ }^{6}$ 


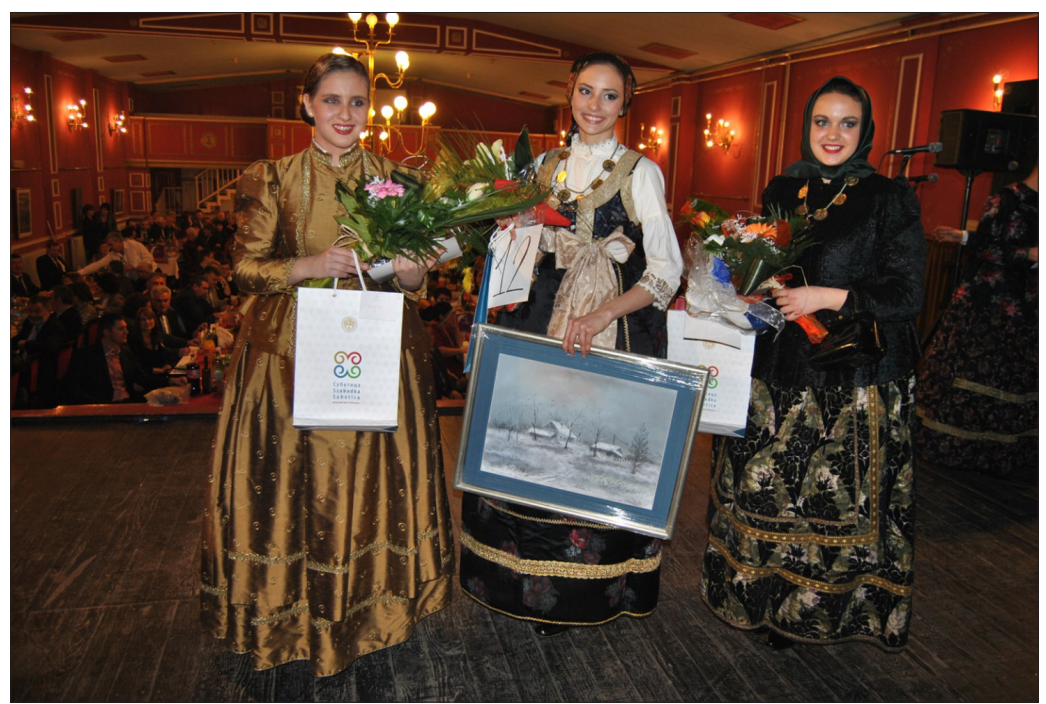

Figure 2. The first three awarded traditional costumes in 2013.

Photograph in possession of the newsweekly Hrvatska riječ.

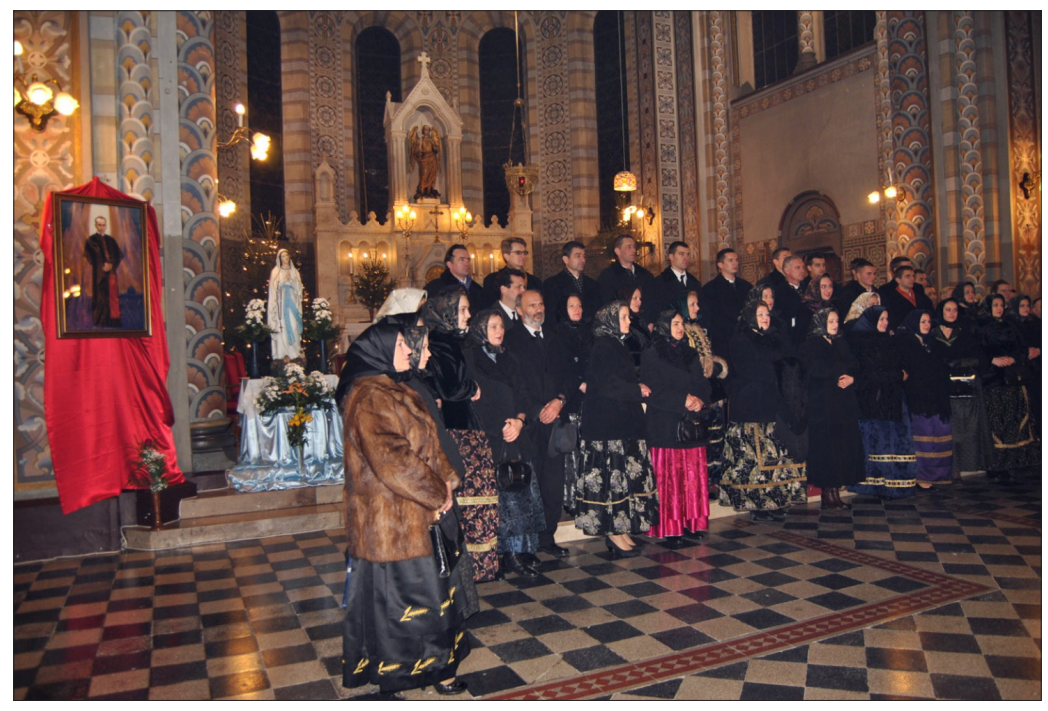

Figure 3. The participants of the prelo sićanja in the Franciscan church in 2013. Photograph in possession of the newsweekly Hrvatska riječ. 


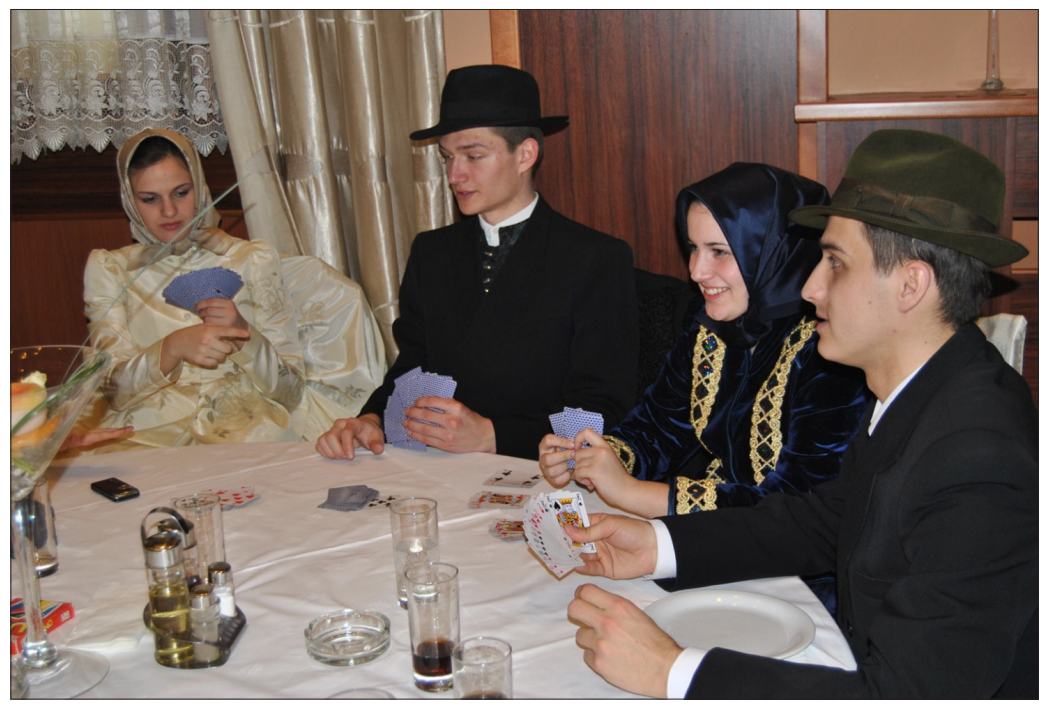

Figure 4. Men and women playing cards. Prelo sićanja in 2013.

Photograph in possession of the newsweekly Hrvatska riječ.

Afterwards, they socialise in a restaurant, accompanied by players on the tambura (a characteristic Croatian long-necked plucked string instrument), eat donuts, drink wine, and play cards. The spinning and other textile crafts are not demonstrated any longer, but both younger and older men play cards, as they used to do in the past, with girls and women joining them nowadays, which was not the case when the prelo was a living tradition (Fig. 4). ${ }^{7}$

\section{PENTECOST PAGEANT}

Another custom that has also undergone revitalisation in the last decade of the 20th century is the Pentecost pageant, which was practiced more or less continuously in the first half of the 20th century. Research based on interviews was combined with the actual observation of the custom itself on Pentecost (called Dove in the local vernacular), in Aleksandrovo and Ker (two parishes in Subotica) on June 12, 2011, in the village of Tavankut and its surroundings in 2013, in Vancaga in Serbia (suburbs of the city of Baja), and in the village Kaćmar, in Hungary, on May 28, 2012. I am dealing only with the custom as observed in Serbia. Although the basic elements of the original custom and ritual practices are recaptured, the revived custom also contains some new elements adapted to the present-day context. The kraljice (meaning queens, 


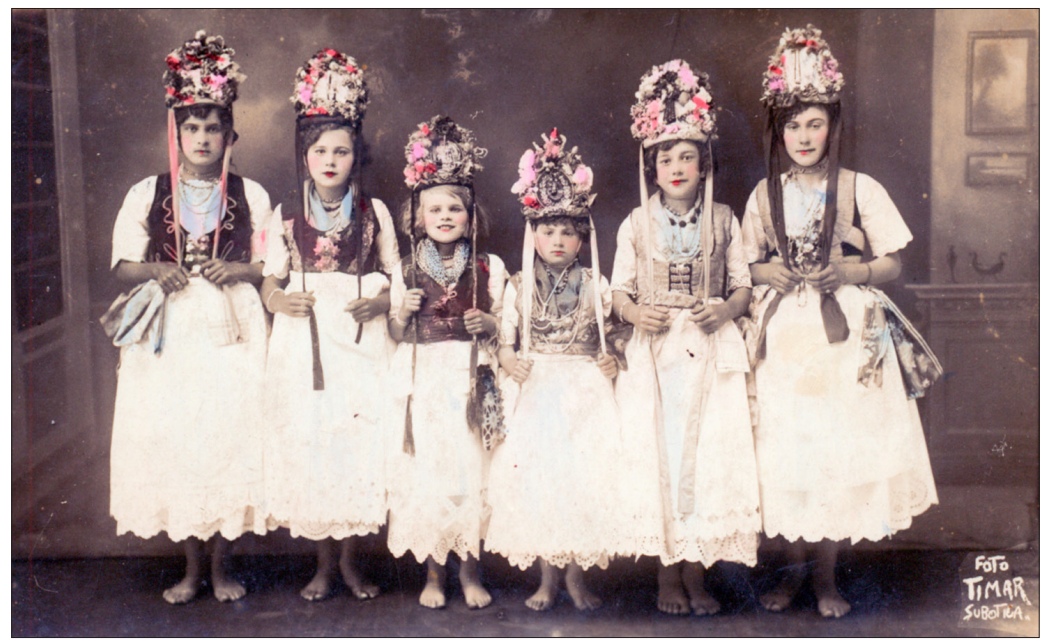

Figure 5. Kraljice in 1932. Photograph in possession of Grgo Piuković, Subotica.

which is the name for young girls performing the pageant) are dressed in the traditional costumes of girls who in earlier times, up to the mid-20th century, performed the pageant barefoot (Fig. 5).

The traditional silk costume alternates with the white embroidered one, but the waistcoat is obligatory in both types of the costume. Older girls that accompany the kraljice are dressed in everyday costume made of industrial cotton, the sefir, with characteristic vertical stripes. They are also accompanied by boys, the shepherds, who collect presents - mainly money nowadays (Fig. 6).

The headdress of the queen is important as well and it differs in the two parishes in Subotica where the custom has been revitalised thanks to the local nuns. In the parish of Ker it is similar to the original one (cf. Figs. 5 and 6), but in the parish of Aleksandrovo nun Eleonora Merkovic decided to change it, since, quoting her words: "it is too heavy for the poor young girls' heads" (Černelić \& Štricki Seg 2014: 217) (Fig. 7).

The kraljice pageant forms a part of various other events during the year: folklore festivals, the festival of the Bunjevci songs, literary evenings, etc. In the past three years, this custom has also been revitalised in the nearby village of Tavankut, organised by the Croatian cultural society in cooperation with the local church authorities. The kraljice wear traditional silk costumes (Fig. 8) (Černelić \& Štricki Seg 2014).

The custom of the kraljice pageant is perceived by the Danube area Bunjevci as a distinctive feature of their own, which sets them apart from the others 


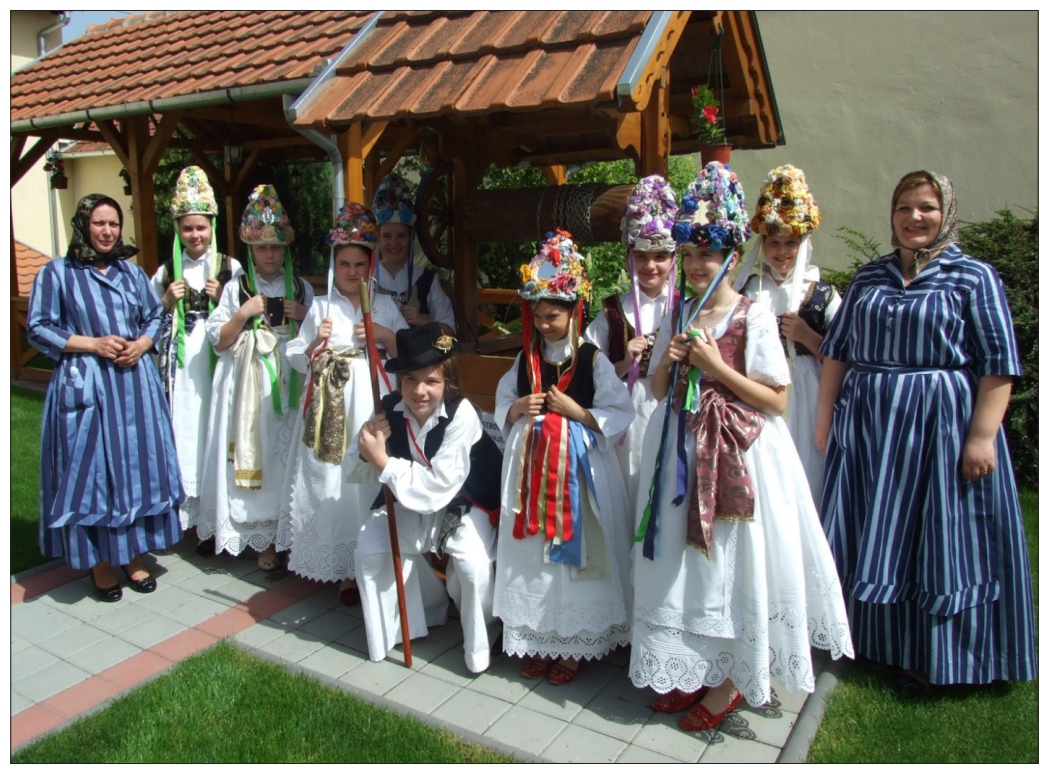

Figure 6. Kraljice in the yard of the family who welcomed young girls during their pageant in the parish of Ker in Subotica in 2013. Photograph in possession of Bernadica Ivanković.

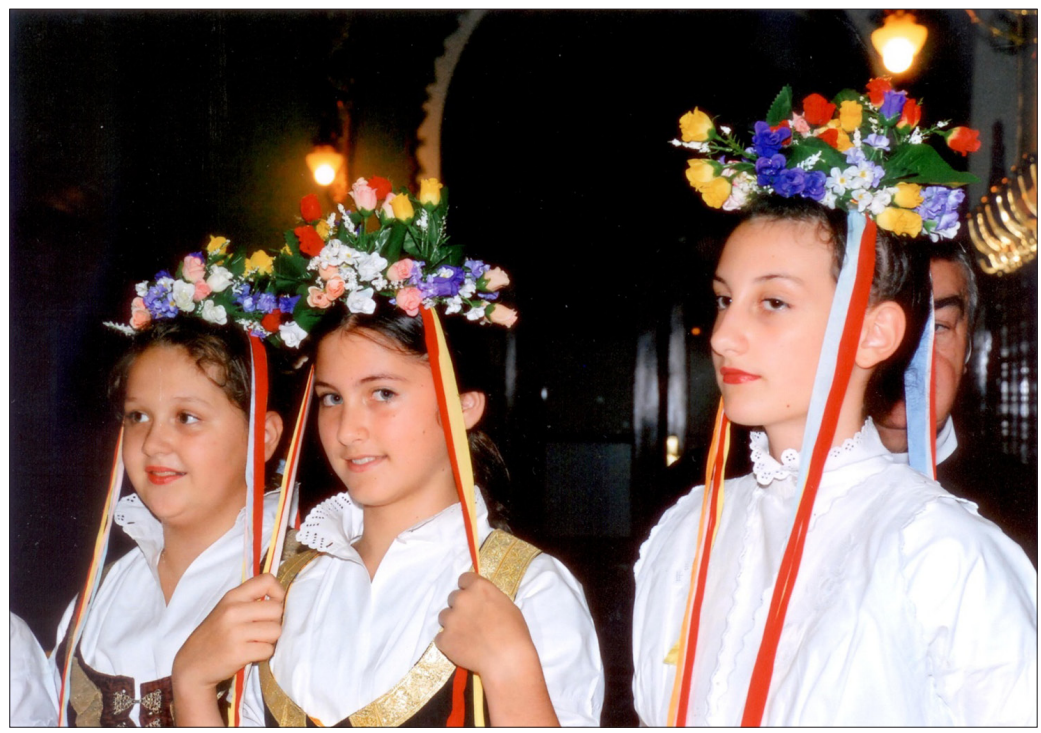

Figure 7. Kraljice in the parish of Aleksandrovo in Subotica in 2010. Photograph in possession of Eleonora Merković. 


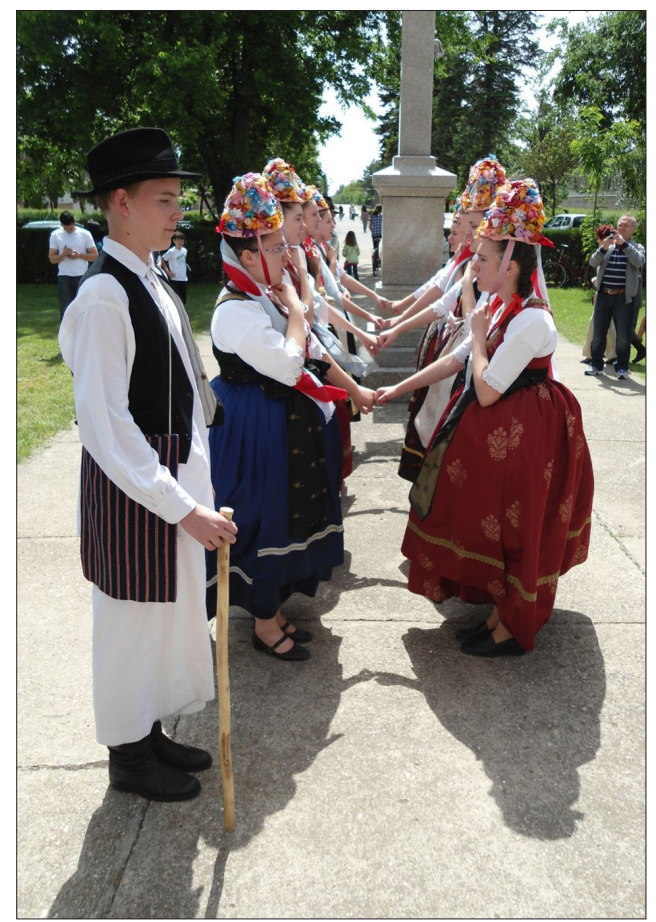

Figure 8. The kraljice sing in front of the church in Tavankut. Photograph by Ivica Dulić 2013.

in their surroundings. The custom is thus translated into a symbol of identity of this Croatian national minority in Serbia. Within a multicultural context its members express their distinctive ethnocultural identity through a public display of certain segments of their traditional heritage. The traditional costume plays an important role in these processes.

\section{DUŽIJANCA}

As already mentioned, Dužijanca is the celebration marking the end of the harvest among the Bunjevci Croats in the region of Bačka, which has existed as a public event for over a century. Being part of the traditional heritage of the Bunjevci, Dužijanca was organised jointly by family members and reapers up to the mid-20th century. The family dužijanca was practiced every summer during the final stage of the harvest, through mutual assistance between families, called moba, which was a common type of economic cooperation on Bunjevci farms up until the period of the Second World War. It was imbued with a religious dimension, giving thanks to God for the collected crop. Blaško Rajić, a priest in St. Rocco's Church in Subotica, first fostered the celebration as a public event in 1911. The leading male and female figures of the harvest (bandaš and bandašica) were selected for the first time in the city of Subotica.

The celebration of Dužijanca lasts for almost four months and includes various festivities of which I will mention only the most important ones: the blessing of the wheat in the fields on St. Mark's Day, April 25, which is the first event of Dužijanca, followed by the competition of reapers in July (which is, in 
fact, the reconstruction of the harvest), an exhibition of articles made in straw technique, artists' colonies (naive art in general and in straw technique), literary evenings, the 'big wheel dance' of the reapers when their male and female leaders are elected, the competition and election of the best-looking traditional costume, etc. After the Holy Mass the procession enters the main town square where the reapers are welcomed and received on stage, which is set to represent the salaš (rural estate). An important part of the performance is giving a symbolic present to the mayor of the town of Subotica: a loaf of bread made from new flour. The celebration of Dužijanca ends with a pilgrimage to the suburban shrine, Bunarić, and a visit to the grave of the priest Blaško Rajić, the founder of the urban celebration of Dužijanca (Černelić \& Grbić Jakopović 2013: 502-509).

The traditional costume acts as an important symbol of Dužijanca, being one of the key elements of the traditional heritage and an outstanding identity marker. The competition of reapers stands as one of the most significant events. It is, in fact, a reconstruction of the authentic harvest. The reapers are dressed in the traditional everyday costumes, similar to those they used to wear during the harvest in the past (Fig. 9). ${ }^{8}$

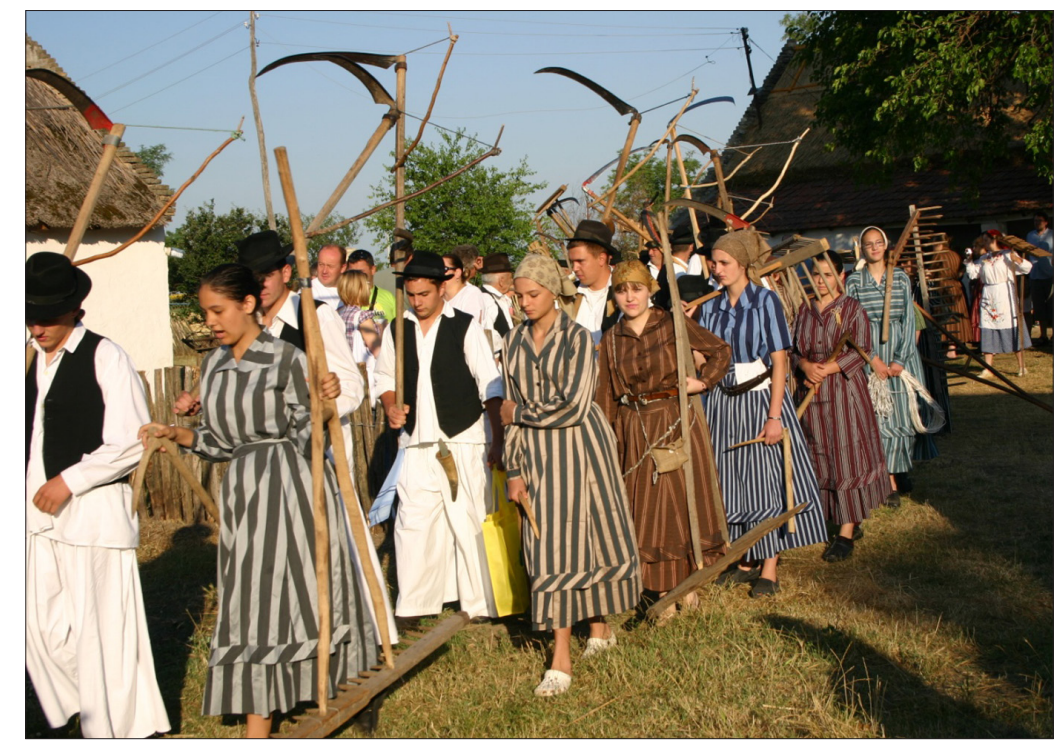

Figure 9. Reapers on their way to the field. Photograph by Nevena Škrbić Alempijević 2012. 


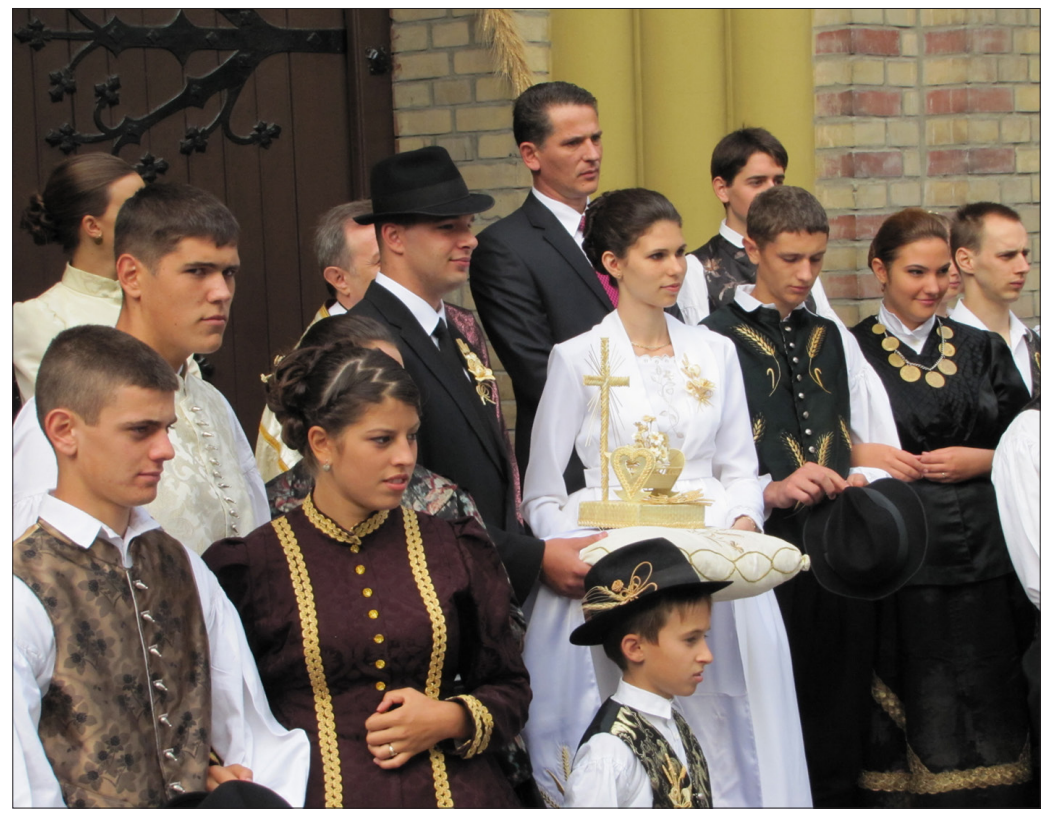

Figure 10. Bandaš and bandašica together with other participants of the procession in front of the church. Photograph by Mihovil Gotal 2012.

The ceremonial traditional dress also forms an important part of Dužijanca. The participants of the procession are dressed in different types of folk costumes, both everyday (sefir) and ceremonial (silk, with white embroidery), along with the leading male and female figure of the harvest, the so-called bandaš and bandašica, who wear ceremonial folk costumes (Fig. 10).

People do not quite agree on what particular type of traditional costume is proper for the occasion. Today girls like to wear white dresses with characteristic embroidery (šlinga), which some of the representatives of cultural associations consider to be improper, because it used to be one of the underlayers of the traditional costume in the past. According to some people, it looks as if someone appeared in the street in their underwear (Škrbić Alempijević \& Rubić 2014: 285).

On the occasion of the 100th anniversary of Dužijanca in 2011 a statue of the reaper dressed in the traditional working costume was erected in the town's central park near the Town Hall, which is also meant to express the identity of the Bunjevci Croats in the region (Fig. 11). Opinions differ as to whether it fits in the urban environment (ibid.: 288).

The mentioned kraljice of both parishes are also involved in the Dužijanca harvest festivity. Those from Ker parish participate in the ceremonial procession - they escort the leading male and female figure of the harvest at the 


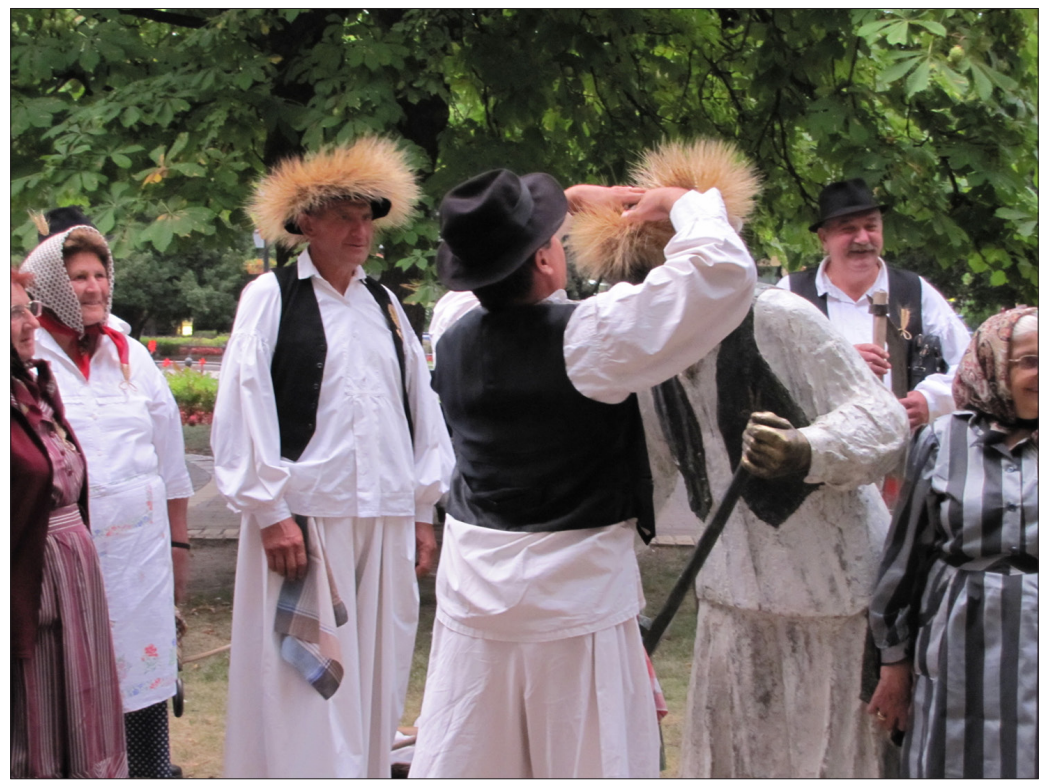

Figure 11. One of the reapers puts a wheat wreath on the hat of the statue of the reaper. Photograph by Mihovil Gotal 2012.

head of the procession, after they have received the priest's blessing in the church. The kraljice from Aleksandrovo parish take part in the pilgrimage to the suburban shrine Bunarić, which is the final event of the Dužijanca harvest festivity (Černelić \& Štricki Seg 2014: 231, 233).

In recent years the custom of lighting bonfires and jumping over them has been revived within the Dužijanca harvest festivity in some rural settlements; originally it was practiced on Midsummer, i.e. St. John's Day. In this way, this custom has been newly revived on the Bunjevci rural estates (salaš) as a vivid reminder of one of the major customs in their ancestors' calendar (Fig. 12).

This custom is closely related to the harvest: many magical beliefs are connected with the protection of the crop from thunder, fire, or vermin. Boys and girls jump over the bonfire, dressed in traditional costumes (Černelić 2014). In the village of Tavankut in 2014, jumping over bonfire was also practiced as part of the Dužijanca harvest festival. In 2015 it was organised separately by the local Croatian cultural association. I had the opportunity to witness the performance of the custom on June 20 of the same year. Today it is not observed exactly on St. John's Day, for practical reasons, but rather on a weekend day closest to this date. Along with the girls and boys dressed in traditional costumes, other participants observing the custom, especially children, join in and jump over the bonfire as well (Fig. 13). 


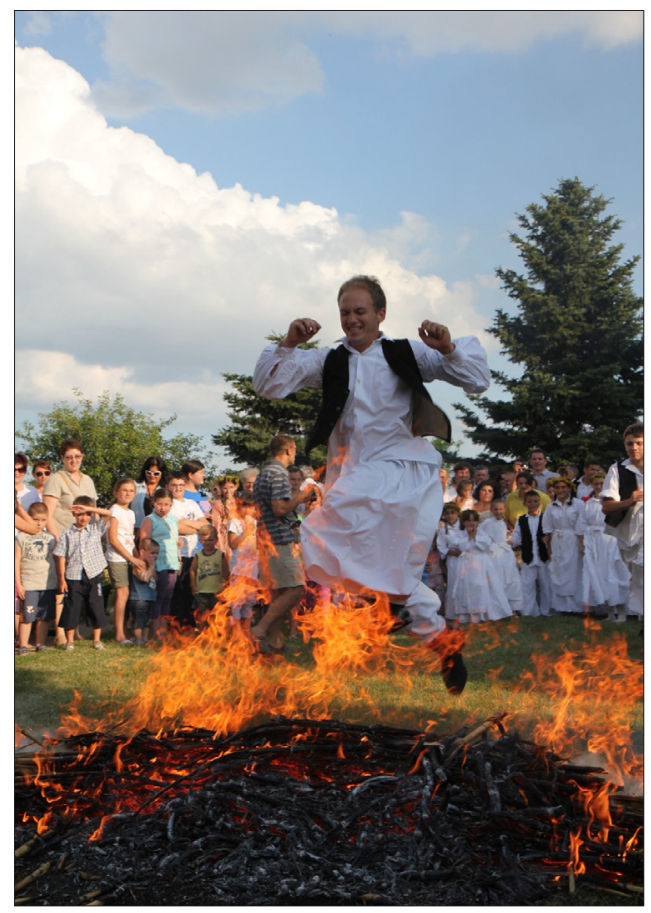

Figure 12. A boy jumping over the fire in the village of Mala Bosna in 2013.

Photograph in possession of the newsweekly Hrvatska riječ.

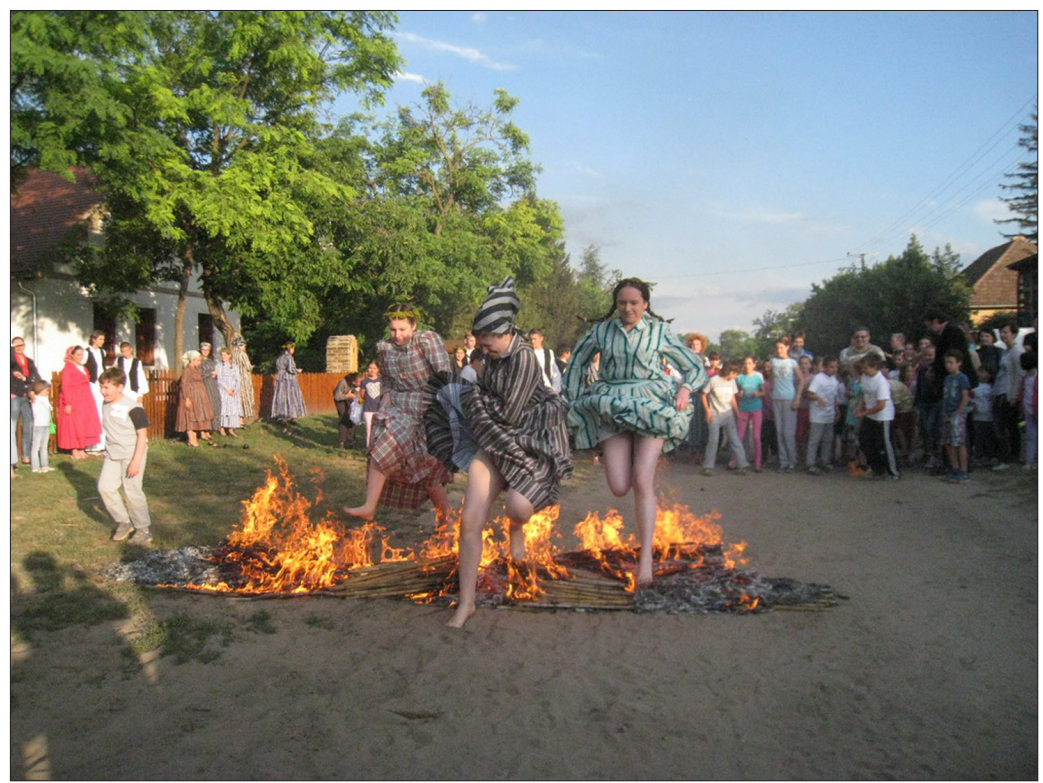

Figure 13. Girls jumping over the fire. Photograph by Katarina Čeliković 2015. 
Dužijanca as one of the most prominent festivities belonging to the cultural heritage of the Bunjevci Croats serves as an important symbol of group identity in the contemporary context. Such a meaning of Dužijanca has found its expression as the key symbol in the culture that comprises various symbolic meanings. ${ }^{9}$

\section{FINAL REMARKS}

The national folk costume plays a very important role in all the mentioned events that occur during the ritual year. Even before Bogatyrev (1937), whose contribution was re-actualised in 1971 (Bogatyrev 1971), in light of semiotic theories, the founder of Croatian ethnology, Antun Radić, in his work titled The Foundation for Collecting and Interpreting Material about Folk Life, pointed to the differences in the function of the traditional costume as well as to the changes in both the style and function of clothing (Radic 1897: 23). ${ }^{10}$

As long as the traditional costume was part of everyday rural life, it had several functions, first of all, practical and aesthetic; the latter was not very comfortable for those who wore the traditional costume, especially girls and women (Bogatyrev 1971: 34-35). An interesting example applied to the Bunjevci case is the nun's intervention on the headdress of the queens, so as to make it more comfortable for the girls to wear. Its function has changed because its purpose is different today - the traditional folk costume is used for ceremonial purposes and as an important means for demonstrating ethnocultural identity.

According to Bogatyrev's (ibid.: 43-44) categories of the transition of the traditional costume through ritual stages and functional changes, the ceremonial holiday costume (the traditional silk costume and girls' white cotton costume decorated with white embroidery) is of crucial importance in the ritual annual customs of the Bunjevci. The function of the everyday costume has also transitioned into ceremonial. It is worn for the purpose of reconstructing the harvest, and on the occasion of jumping over the fire on St. John's Day; so it has taken on a ceremonial function nowadays, to recall and revitalise traditional costumes as originally as possible in the present day context (most often the sefir, made from industrial cotton with characteristic vertical stripes). Over the past several decades, the traditional costume has also stood for a national symbol and, as such, has played an important role in all the analysed customs as a symbolic object and an ethnocultural marker of the identity of the subethnic and national minority group of the Bunjevci Croats in Serbia. Their ambivalent position, as depicted earlier, seems to reflect their intense need to further demonstrate their ethnocutural heritage. 


\section{NOTES}

1 As already mentioned, similar tendencies already appeared during the political regime of the Kingdom of Yugoslavia and even earlier. It is not possible to present in detail all historical (and political) circumstances that affected the aspects of constructing the identity of the Bunjevci in Bačka.

2 Šokci is another Croatian subethnic group in Bačka.

3 The scientific project Identity and Ethnocultural Shaping of the Bunjevci, approved and financed by the Croatian Ministry of Science, Education and Sports, was carried out between 2008 and 2013, and dealt with all three Bunjevci branches. Research results on the Danube area Bunjevci are published in the monograph Traditional Heritage and Ethnocultural Identity of the Bunjevci Croats in the Danube Area (2014). The research was realised by me as a project leader, my project associates, and students. Our articles are published in the mentioned monograph.

4 The purpose of this article is not to give a thorough presentation of the traditional costume. It would include more complex analyses of different types of traditional costumes according to gender, age, season, and occasion, including the transformations starting from the late 19th century, which is not possible to provide in such a short account.

5 Much more detail on the mentioned costumes, as well as on some other parts of the traditional costume of the Bunjevci can be found in Sekulic 1991, Maglica 1998, Suknović 2010.

6 See Sudarević 2012.

7 Ibid.

8 See more about the competition of reapers and about Dužijanca through the prism of collective memory in Škrbić Alempijević \& Rubić 2014.

9 See more about various symbolic aspects of Dužijanca in Škrbić Alempijević \& Rubić 2014; Vugdelija \& Gotal 2013.

${ }^{10}$ See more about his contribution in Bonifačić 1995/1996.

\section{REFERENCES}

Banac, Ivo 1992. Protiv straha: Clanci, Izjave i Javni Nastupi, 1987-1992. [Against Fear: Articles, Statements, and Public Speeches.] Zagreb: Slon.

Bogatyrev, Petr 1971. The Functions of Folk Costume in Moravian Slovakia. The Hague \& Paris: Mouton.

Bonifačić, Vjera 1995/1996. Antun Radić and Ethnological Research of Clothing and Textiles in Croatia: 1896 to 1919. Studia ethnologica Croatica, Vol. 7/8, No. 1, pp. 161-179. Available at http://hrcak.srce.hr/file/90199, last accessed on September 15, 2016. 
Černelić, Milana 1997. Attempts to Deny the Bunjevci of Bačka (Vojvodina) the Right to Belong to the Croat Nation. Acta Ethnographica Hungarica, Vol. 42, Nos. 1-2, pp. 175-186.

Černelić, Milana 2006. Bunjevačke studije. [The Bunjevci Studies.] Zagreb: FF press.

Černelić, Milana 2012. The Impact of Migration on the Cultural Heritage and Identity: The Example of the Croatian (Sub)ethnic Group Bunjevci. In: Petko Hristov (ed.) Migration and Identity: Historical, Cultural and Linguistic Dimensions of Mobility in the Balkans. Sofia: Paradigma, pp. 163-179.

Černelić, Milana 2014. Sveti Ivan Cvitnjak. [Saint Ivan Cvitnjak: Saint John's Day.] In: Tradicijska baština $i$ etnokulturni identitet podunavskih Hrvata Bunjevaca. [Traditional Heritage and Ethnocultural Identity of the Bunjevci Croats in the Danube Area.] Zagreb \& Subotica: FF press \& Zavod za kulturu vojvođanskih Hrvata, pp. 265-273.

Černelić, Milana \& Grbić Jakopović, Jadranka 2013. Sto i dvije godine trajanja Dužijance - proslava završetka žetve kao kulturna praksa i iskazivanje identiteta. [A Hundred and Two Years of Dužijanca: The Celebration Marking the End of Harvest as a Cultural Practice and an Expression of Identity.] In: Mira Muhoberac (ed.) Medunarodni znanstveni interdisciplinarni simpozij Hrvatska folklorna i etnografska baština u svjetlu dubrovačke, svjetske i turističke sadašnjosti. FEB 2012. Dubrovnik, Republika Hrvatska, 11.-13. prosinca 2012. Zbornik radova. [International Scientific Interdisciplinary Symposium: Croatian Folklore and Ethnographic Heritage in Light of Dubrovnik, World and Tourist Present.] Dubrovnik: Folklorni ansambl Linđo, pp. 500-515.

Černelić, Milana \& Štricki Seg, Tamara 2014. Ophodi kraljica. [The Pentecost Pageant.] In: Milana Černelić (ed.) Tradicijska baština i etnokulturni identitet podunavskih Hrvata Bunjevaca. [Traditional Heritage and Ethnocultural Identity of the Bunjevci Croats in the Danube Area.] Zagreb \& Subotica: FF press \& Zavod za kulturu vojvođanskih Hrvata, pp. 191-238.

Cohen, Anthony P. 1985. The Symbolic Construction of Community. London: Tavistock. Dronjić, Matija 2014. Etnografske crtice o prelima kod Bunjevaca u Subotici i okolici. [Ethnological Notes on Prelo among the Bunjevci in Subotica and its Surroundings.] In: Milana Černelić (ed.) Tradicijska baština i etnokulturni identitet podunavskih Hrvata Bunjevaca. [Traditional Heritage and Ethnocultural Identity of the Bunjevci Croats.] Zagreb \& Subotica: FF press \& Zavod za kulturu vojvođanskih Hrvata, pp. 109-134.

Maglica, Nadja 1998. Predajno odijevanje bačkih Hrvata Bunjevaca. [The Traditional Dress of the Bunjevci Croats from Bačka.] In: Milana Černelić \& Nevenka Fabian \& Tihana Petrović \& Marija Šercer \& Naco Zelić \& Marija Zaić Kubatović (eds.) Iz baštine bačkih Hrvata Bunjevaca. [From the Heritage of the Bunjevci Croats in Bačka.] Zagreb: Etnografski muzej u Zagrebu, pp. 12-17.

Prelić, Mladena 2008. Identitet i praznik. Dužijanca Bunjevaca u Bačkoj. [Identity and Holiday. Dužijanca among Bunjevci in Bačka.] In: Mato Pižurica \& Suzana Kujundžić-Ostojić (eds.) Etnolingvistička i istorijska istraživanja o Bunjevcima. [Ethnolinguistic and Historical Research on Bunjevci.] Novi Sad \& Subotica: Matica srpska i NIU Bunjevački informativni centar, pp. 125-136. 
Radić, Antun 1897. Osnova za sabiranje i proučavanje građe o narodnom životu. [The Foundation for Collecting and Interpreting Material about Folk Life.] Zbornik za narodni život i običaje Južnih Slavena, knj. 2. Available at http://dizbi.hazu. hr/object/13491, last accessed on September 15, 2016.

Sekulić, Ante 1991. Bački Hrvati: narodni život i običaji. [The Bunjevci Croats from Bačka: Folk Life and Customs.] Zbornik za narodni život i običaje Južnih Slavena, Vol. 52. Zagreb: Academia Scientiarum et Artium Slavorum Meridionalium.

Škrbić Alempijević, Nevena \& Rubić, Tihana 2014. Dužijanca bunjevačkih Hrvata u Subotici: tvorba tradicije, izvedba sjećanja. [Subotica Dužijanca: Creation of Tradition, Performance of Memory.] In: Milana Černelić (ed.) Tradicijska baština $i$ etnokulturni identitet podunavskih Hrvata Bunjevaca. [Traditional Heritage and Ethnocultural Identity of the Bunjevci Croats in the Danube Area.] Zagreb \& Subotica: FF press \& Zavod za kulturu vojvođanskih Hrvata, pp. 275-293.

Sudarević, Nada 2012. Prelo sićanja u HKC-u "Bunjevačko kolo". [The Memory Spinning Bee in the Croatian Cultural Centre "Bunjevačko kolo".] February 19. Available at https://www.subotica.info/2012/02/19/prelo-sicanja-u-hkc-u-bunjevacko-kolo, last accessed on September 14, 2016.

Suknović, Kata 2010. Bunjevačka narodna nošnja. [The Bunjevci Folk Costumes.] Available at http://zkvh.org.rs/index.php/bastina/tradicijska-kultura/309-bunjevakanarodna-nonja, last accessed on September 15, 2016.

Vugdelija, Kristina \& Gotal, Mihovil 2013. Dužijanca kao simbol suvremenog identiteta Hrvata Bunjevaca. [Dužijanca as a Symbol of Contemporary Identity of the Bunjevci Croats.] Godišnjak za znanstvena istraživanja, Vol. 5, pp. 167-183. Available at http://www.zkvh.org.rs/index.php/godisnjak-articles/44-etnologija/2824vukdelijaagotal-2013, last accessed on November 3, 2016.

Žigmanov, Tomislav 2006. Hrvati u Vojvodini danas: Traganje za identitetom. [Croats in Vojvodina Today: In Search of Identity.] Zagreb: Hrvatska sveučilišna naklada. 